\title{
Undergraduates' Involvement in Entrepreneurial Opportunities and Attitude to Academic Work: Implications for Counselling
}

\author{
Ajidahun, Beatrice Olawumi, Phd. \\ Department of Guidance and Counselling, \\ Faculty of Education, Adekunle Ajasin University, \\ Akungba Akoko, Nigeria
}

Doi: 10.1515/ajis-2017-0016

\begin{abstract}
This study examines how undergraduates' involvement in entrepreneurial opportunities and co-curricular activities affects their attitudes to academic work, and the place of counselling in resolving the conflict of interest experienced among the students. Many undergraduate students dabble into entrepreneurial activities without considering their impacts on their academic work. A lot of undergraduates have exchanged their academic work for business, and this has jeopardized their academic integrity. One hundred undergraduate students were sampled from Adekunle Ajasin University, Akungba Akoko using a questionnaire titled 'Entrepreneurial Questionnaire'. Descriptive sample technique was used, and the data was analysed using chi square analysis. Four hypotheses were formulated and tested at 0.05 level of significance. The four hypotheses tested were rejected. The results imply that there is significant relationship between undergraduates' involvement in entrepreneurial activities attitude to academic work. There is significant relationship between involvement of male and female in entrepreneurial activities. Co-curricular and entrepreneurial activities were significantly related. Counselling strategies were recommended to help undergraduates to understand the fact that academic integrity is an important University value, and also that undergraduates can involve in entrepreneurial activities during vacation period to avoid conflict of interest with their academic work.
\end{abstract}

Keywords: Entrepreneurial Involvement, Undergraduates, Attitude, Academic work, Counselling

\section{Introduction}

University education requires a lot of commitment on the part of the students for them to excel and to have adequate skills that are expected of them as qualified graduates. The course content of undergraduate programmes is very elaborate and comprehensive. It implies therefore that there may not be room for other activities that take ample time from their objective of being in school. Some undergraduates, who are combining other activities with their academic work, may not come out with good class. The testimonies of students that graduated with first class revealed that total concentration on academic studies is better than being distracted from other activities either within or outside the University.

The University course content is divided into three basic aspects, the Departmental courses, Faculty courses and the University courses. Among the University courses are the general courses also known as GST and Entrepreneurship courses also known as ENT. An Entrepreneurial study was included in the programmes of undergraduates in 2005, when the Universities' Minimum Academic Standard was revised. According to Onifade (2004), the rationales for the inclusion of entrepreneurial studies were purposely to reposition Nigerian University system to produce knowledgeable skilled and entrepreneurial graduates that would meet the need of the labour 
market.

In the past, the labour market was not very competitive as to what obtains today. Undergraduates had jobs begging for them before they graduated from the school. The number of Nigerians in the higher institutions then cannot be compared to what is happening now. The population of graduates produced in Nigerian Universities have greatly increased because the number of Universities in the nation has also increased as well. Both the federal and state Universities have increased in numbers in addition to the private Universities. The programmes in the University too have been enlarged to include part-time programmes, degree and sandwich degree programmes. All these programmes produce thousands of graduates every year and the available space for job cannot accommodate all the graduates seeking for job. Based on this problem, the government and the University authorities saw the need to reposition University education by emphasising entrepreneurial skills acquisition among University students.

Another reason why entrepreneurial skills need to be acquired by undergraduates is to eradicate poverty in the nation. Poverty level is very high in the country because the available resources cannot go round the populace. In order to avoid premature death, emotional problems and the likes, there is the need to acquire entrepreneurial skills in schools which will be useful after graduation. Hodgetts (2010) observed that people can die young in regions where there is income inequality and that poorer people are at greater risk for premature death. This implies that poverty can cause people to perish or die untimely death.

The closure of some industries had caused unemployment and the white collar jobs available cannot go round everybody. Acquisition of entrepreneurial skills is important to solve the above problems. Advancement in science and technology has also changed the image of the labour market. Computer literacy is now the order of the day because information economy has come to replace labour economy. Works that were done by people in the past are now being done by computerised machines. Only those who are computer literate can operate such machines. So, any undergraduate who has not acquired entrepreneurial skills before graduating may find it difficult to survive in the labour market. Such undergraduates who lack skills may not be able to cope financially if white collar jobs are not found after leaving school. Such graduates may be jobless due to the fact that they are still looking for jobs that suit the certificates they have acquired. Because of the fear of unemployment, some students are combining their academic work with entrepreneurial activities. They have business ventures they are running together with their full time studies.

Introduction of entrepreneurial studies at the University level was purposely to solve the problem of idleness, joblessness and the likes after graduation not while still studying in school. Entrepreneurial studies are taught with other academic courses. Academic education according to Moore et al (2010) aims at producing intelligent, responsible, well informed citizens who will take active interest in the world around them. Entrepreneurial education was included in the curricular of academic education to prepare the graduates for self-employment after graduation. It is selfemployment education that helps a person to organise, operate, and assume the risk for a business venture.

Entrepreneurship is one of the four mainstream economic factors: land, labour, capital and entrepreneurship. The word itself was derived from $17^{\text {th }}$ century French enterprendre- It refers to individuals who were 'undertakers' It means those who undertake the risk of new enterprise. According to Enikanselu and Oyende (2009), entrepreneurship is the dynamic process of creating incremental wealth. This wealth is created by individuals who assume the major risks in terms of equity, time, or career commitment of providing value for some products or services.

The main purpose of entrepreneurial studies includes the following:

- To teach undergraduates the art of managing small scale business with a view to making them self-reliant.

To equip the students with entrepreneurship skills, which they can use when they get out of school, if they are unable to find jobs in view of the high unemployment in Nigeria.

- To stimulate students' creativity and their desire to start their own business after graduation.

- To stimulate students to take responsibility and initiative.

- To give young people an understanding of product/service business values in 
accordance with fundamental ethical principles.

The educational mission of University is to develop the whole students. Students' involvement in entrepreneurial activities is different from co-curricular involvement. Co-curricular key tool in the personal development of the students plays an integral role in the collegiate experince. The involvement of students in co-curricular activities is not only for entertainment, social and enjoyment purposes, but most importantly, to gain improved skills. According to Pascarell and Terenzini (1991), co-curricular activities impact the following on students:

- To complement the University's academic curriculum and to augment the students educational experience.

- To provide a setting to become involved and to interact with other students leading to increased learning and enhanced development.

- To increase peer involvement and influence on students' academic and personal developments.

- To help students to mature socially by providing a setting for students' interaction, relationship formation and discussion.

- To gain more self-confidence, autonomy and appreciation for others' difference and similarities.

- To allow students to link academic knowledge with practical experience, thereby leading to a better understanding of their ability, talents and career goals.

These numerous experiences of co-curricular activities enable students to develop positive emotional, intellectual, social and inter -personal skills by working together with other individuals. Engaging in co-curricular activities also helps undergraduates to learn how to negotiate, communicate, and manage conflicts and other related issues. Taking part in these out of classroom activities helps students to understand the importance of critical thinking, skills, and time management, academic and intellectual competence. Working outside the classroom with diverse group of individuals helps students to gain more self- confidence, autonomy and appreciation of others 'differences and similarities. The common co-curricular activities in the University system are the following:

- Student Union

- Sports

- Academic and Departmental organisations

- Religious organisations

- Multicultural Activities

The involvements of undergraduates in both entrepreneurial and co-curricular activities have effect on their attitude to academic work. Many undergraduate who are not able to cope have dropped out of the University. According to Harding (2003), school dropouts are likely to be unemployed; they make lower salaries if employed. Many of such undergraduates are exposed to menial jobs, and are therefore engaged as cleaners, drivers, cashiers, sales boys or girls and the likes. The reasons are grave; many of such drop-outs have not acquired skills to cope in professional jobs. Lane and Cherck (2001) opine that dropouts are also more likely to show behavioural problems including, criminal behaviour and substance abused. The psychological effects of having many carry-over courses to re- write and the shame attached to the conditions may prompt such students to drop out of school.

Another variable responsible for participating in entrepreneurial and co-curricular activities is the parental factor. Landau (2004) observed that, by the time the undergraduates entered the higher institution, many parents surveyed admitted that they did not know who their children's friends were or where their children went and what they did after school has vacated. Many parents said they would have loved to be involved in their children school and leisure activities but that they are just too busy. When parents are too busy to follow up their children's academic work, many things are taken for granted.

Truancy is common among students who are involved in either entrepreneurial activities or co-curricular activities and this can also lead to drop out problems. According to Lever (2004), excessive school absence and reading below class level are two of the earliest and strongest 
predictors of school dropout. Woolfolk (2004) identified poor problem solving ability, low selfesteem, problems with lecturers, dissatisfaction with school, substance abuses, and being male students as other risk factors responsible for school dropout.

\section{Purpose of the Study}

The purpose of this study is to investigate whether the involvement of undergraduates in entrepreneurial and co-curricular activities has any relationship with their academic work. Also, the study aims at finding out whether more males than females engage in entrepreneurial and cocurricular activities.

\section{Hypothesises}

For the purpose of this study four hypotheses were formulated and tested at 0.05 of significance.

1. There is no significant relationship between undergraduates' involvement in entrepreneurial activities and attitude to academic.

2. There is no significant relationship between undergraduates' involvement in entrepreneurial activities and co-curricular activities.

3. There is no significant relationship between male and female entrepreneurs and their attitude to academic work.

4. There is no significance relationship between undergraduates who are involved in entrepreneurial activities and those who are not involved

\section{Methodology}

\subsection{Population and Sampling Procedure.}

The population of the study consists of all regular students in Adekunle Ajasin University. A total number of 100 students were randomly sampled. Simple random sampling technique was used to sample the students.

\subsection{Research Instrument}

The research instrument used for the study was a self-constructed questionnaire titled Entrepreneurial Questionnaires (E Q). The questionnaire consists of 20 items. Section A contains twenty items which are relevant to the study. Four Likert scale of Strongly Agree, Agree Strongly disagree and Disagree was used.

\subsection{Data Analysis}

The data were analysed using chi-square statistical method. All hypotheses were tested at 0.05 level of significance.

\section{Findings}

\subsection{Hypothesis One}

There is no significant relationship between undergraduates' involvement in entrepreneurial activities and attitude to academics 
Table 1:

\begin{tabular}{|c|l|c|c|}
\hline S/N & Items & Agree & Disagree \\
\hline 1 & $\begin{array}{l}\text { Students who participate in entrepreneurial activities are not punctual in } \\
\text { lectures most of the time. }\end{array}$ & 75 & 25 \\
\hline 2 & $\begin{array}{l}\text { Students who are regular in class perform better than those who are not } \\
\text { regular because of their involvement in entrepreneurial activities. }\end{array}$ & 60 & 40 \\
\hline 3 & $\begin{array}{l}\text { Full-time students who are not engaged in entrepreneurial activities have } \\
\text { more time for academic activities than those who are involved. }\end{array}$ & 73 & 27 \\
\hline 4 & $\begin{array}{l}\text { Students who are not involved in entrepreneurial activities sometimes come } \\
\text { out with good class than those who are involved. }\end{array}$ & 62 & 38 \\
\hline 5 & $\begin{array}{l}\text { Entrepreneurial students have money more than non-entrepreneurial students } \\
\text { to cover their lapses. }\end{array}$ & 71 & 29 \\
\hline 6 & $\begin{array}{l}\text { Entrepreneurial students have money to settle their friends who are writing } \\
\text { tests, assignments etc on their behalf. }\end{array}$ & 73 & 27 \\
\hline 7 & $\begin{array}{l}\text { Students who engage in entrepreneurial activities are more or less like part- } \\
\text { time students than full -time students. }\end{array}$ & 73 & 27 \\
\hline 8 & $\begin{array}{l}\text { Students who are involved in entrepreneurial activities have no written lecture } \\
\text { notes to read for examination other than photocopies of notes from colleagues } \\
\text { that may be full of errors. }\end{array}$ & 67 & 33 \\
\hline 9 & $\begin{array}{l}\text { Assignments are submitted promptly and adequately by students who are not } \\
\text { involved in entrepreneurial activities than those who are involved. }\end{array}$ & 57 & 43 \\
\hline 10 & Total & 611 & 289 \\
\hline
\end{tabular}

The above table reveals that the calculated chi- square value which is 12.80 is greater than the table value which is 3.841 . Hence, the result is significant. Therefore, the null hypothesis was rejected.

\subsection{Hypothesis Two}

There is no significant relationship between undergraduates' involvement in entrepreneurial activities and co-curricular activities.

\section{Table 2:}

\begin{tabular}{|c|l|c|c|}
\hline S/N & Items & Agree & Disagree \\
\hline 1 & $\begin{array}{l}\text { More students engage in entrepreneurial activities and co-curricular activities } \\
\text { because of the financial benefit. }\end{array}$ & 76 & 24 \\
\hline 2 & $\begin{array}{l}\text { Co-curricular activities augment students' educational experience than their } \\
\text { involvement in entrepreneurial activities as students. }\end{array}$ & 70 & 30 \\
\hline 3 & $\begin{array}{l}\text { Students' involvement in co-curricular activities can be curbed by the University } \\
\text { authority if academic activities are affected, but entrepreneurial activities cannot be } \\
\text { curbed like that. }\end{array}$ & 80 & 20 \\
\hline 4 & $\begin{array}{l}\text { Some students engage in co-curricular activities for financial gain not because of the } \\
\text { interest to serve others. }\end{array}$ & 72 & 28 \\
\hline 5 & $\begin{array}{l}\text { The level of risks students are exposed to because of their involvement in } \\
\text { entrepreneurial activities is higher than when they are involved in co-curricular activities. }\end{array}$ & 86 & 14 \\
\hline & TOTAL & 384 & 116 \\
\hline
\end{tabular}

\begin{tabular}{|l|l|c|c|}
\hline & Averaged observed Response & df & $\mathrm{X}^{2}{ }_{\mathrm{c}}$ \\
\hline Agree & $76.8(50)^{*}$ & 1 & 28.72 \\
\hline Disagree & $\mathbf{2 3 . 2 ( 5 0 ) ^ { * }}$ & & \\
\hline Total & 100 & & \\
\hline
\end{tabular}

${ }^{*}$ Expected Cell Frequency 
The table reveals that the calculated chi-square value which is 28.72 is greater than the table value which is 3.841 . Hence the result is significant. Therefore, the null hypothesis was rejected.

\subsection{Hypothesis Three}

There is no significant relationship between male and female entrepreneurs and their attitude to academic work.

\section{Table 3:}

\begin{tabular}{|c|l|c|c|}
\hline S/N & Items & Agree & Disagree \\
\hline 1 & More males than females engage in entrepreneurial activities as full time students. & 78 & 22 \\
\hline 2 & $\begin{array}{l}\text { Females are likely to be more distracted when involved in entrepreneurial activities } \\
\text { than the male counterparts. }\end{array}$ & 79 & 21 \\
\hline 3 & $\begin{array}{l}\text { Male students have the strength to combine their academic work with } \\
\text { entrepreneurial activities than the female students. }\end{array}$ & 75 & 25 \\
\hline 4 & $\begin{array}{l}\text { Male students who are involved in entrepreneurial activities have more opposite } \\
\text { sex as friends. }\end{array}$ & 66 & 34 \\
\hline & TOTAL & 298 & 102 \\
\hline
\end{tabular}

\begin{tabular}{|l|l|c|c|}
\hline & Averaged observed Response & $\mathrm{df}$ & $\mathrm{X}^{2}{ }_{\mathrm{c}}$ \\
\hline Agree & $74.5(50)^{*}$ & 1 & 24.01 \\
\hline Disagree & $\mathbf{2 5 . 5 ( 5 0 ) ^ { * }}$ & & \\
\hline Total & 100 & & \\
\hline
\end{tabular}

The table reveals that the calculated chi-square value which is 24.01 is greater than the table value which is 3.841 . Hence the result is significant. Therefore, the null hypothesis was rejected.

\subsection{Hypothesis Four}

There is no significance relationship between undergraduates who are involved in entrepreneurial activities and those who are not involved.

\section{Table 4:}

\begin{tabular}{|c|l|c|c|}
\hline $\mathrm{S} / \mathrm{N}$ & Items & Agree & Disagree \\
\hline 1 & $\begin{array}{l}\text { Entrepreneurial students suffer conflict of interest between their academic } \\
\text { works and their businesses. }\end{array}$ & 73 & 27 \\
\hline 2 & $\begin{array}{l}\text { Some undergraduates are involved in entrepreneurial activities simply } \\
\text { because of the reality of unemployment after graduation. }\end{array}$ & 66 & 34 \\
\hline & TOTAL & 139 & 61 \\
\hline & & & \\
\hline
\end{tabular}

\begin{tabular}{|l|l|c|c|}
\hline & Averaged observed Response & df & $X^{2}{ }_{c}$ \\
\hline Agree & $69.5(50)^{*}$ & 1 & 15.21 \\
\hline Disagree & $\mathbf{3 0 . 5}(\mathbf{5 0})^{*}$ & & \\
\hline Total & 100 & & \\
\hline
\end{tabular}

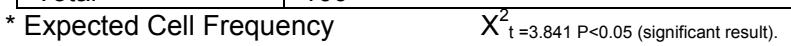

The table shows that the calculated chi-square value which is 15.21 is greater than the table value which is 3.841 . Hence the result is significant. Therefore, the null hypothesis was rejected.

\section{Discussion}

The results in table 1 indicate that there is significant relationship between undergraduates' 
involvement in entrepreneurial activities and their attitude to academic work. This implies that when full-time undergraduates are involved in entrepreneurial activities, their academic works may suffer. This finding corroborates with Onifade (2004) that entrepreneurial activities are expected to be practiced after graduation. But, in reality many students are involved while in school to augment their financial capability. Majority of the respondents used for the research work are from average families. According to Landau (2004) because many parents may not be concerned about their children's university academic work this parental attitude can lure many to be involved in entrepreneurial activities without their parent consent.

Table 2 shows that there is significant relationship between undergraduates' involvement in both entrepreneurial activities and co-curricular undergraduate activities. This implies that undergraduates' attitudes to academic works may be affected by being involved in entrepreneurial activities or co-curricular activities. The findings negate the assertion of Pascarella and Terenzini that co-curricular activities help undergraduates to have better understanding of their abilities, talents and career goals. The involvement of students in entrepreneurial and co-curricular activities made them to travel a lot and by so doing they may be absent for their lectures. Lever (2004) opined that excessive school absence may lead to dropping out of the University. Monetary gains lure many undergraduates into entrepreneurial and co-curricular activities at the expense of their academic work.

Table 3 reveals that there is significant relationship between male and female undergraduate entrepreneurs who engaged in entrepreneurial activities. This shows that gender is not the issue but the lack of concentration experienced by both sexes. Both male and female who are involved in entrepreneurial activities have the tendency to slack with their academic work. Woolfolk (2004) asserted that although the male students are more at risk of having problem with lecturers, low selfesteem, substance abuse and drop out problem some females are not left out possessing some of the problems.

Table 4 reveals that there is significant relationship between those who engaged in entrepreneurial activities and those who were not involved. Those who were not involved have ample time to concentrate on their studies than those who were involved. Those who were not involved have less distraction, and were able to complete their studies instead of dropping out because of other activities. Those who are involved may have more money to spend than those who are not. Harding(2003) when students dropped out of school due to failure they are likely to be exposed to menial jobs and may develop behavioural problems as observed by Lane and Cherch(2001) that drop out students are faced with behavioural problem.

\section{Conclusion}

The change in government policy not to provide accommodation and cafeteria services had prompted many students to be involved in entrepreneurial activities to cater for themselves. Even though the programme is designed for the students after their schooling, the economic situation of the country is dictating another signal. To manage both academic work and entrepreneurial activities require a strong and committed student. Zunker (2006) observed that undergraduates are to sustain their careers through a lifelong learning that includes the development of all life roles. They ought to face their studies squarely and come out with good grades. Employers see university graduates as possessing requisite skills and values that make them more desirable for employment and advancement. Individuals with degrees are more likely to obtain high status in managerial, technical and professional jobs.

\section{Recommendations}

- Since industrial attachment experiences can provide undergraduates with opportunities to observe ongoing activities in his or her major field of study and to interact with individuals on the job. It would be better for them to exercise caution and wait till they are through with their courses before engaging in entrepreneurial activities. The extern experience differs from engaging in entrepreneurial activities. 
- The extern experiences are of short duration usually during the semester breaks. And it may not affect the real academic work. Students can make use of their semester break to earn money instead of combining them with their academic work. The experience will last long than the one they are doing daily hurriedly because of money

- Psychological tension experienced by the undergraduates who are into business can be avoided if such venture is delayed to when academic works are over.

\section{References}

Enikanselu, S.A. and Oyende, A. I. (2009). Entrepreneurship Development and Management of Small Scale Enterprises. Lagos: Enylcon Consult.

Harding, D.J. (2003). "Counterfactual Model of Neighbourhood Poverty on Dropping out Teenage Pregnancy. American Journal of Sociology. 109 (5) 676-715.

Landau, B.S.M. (2004). The Art of Classroom Management Building Equitable Learning Communities. $2^{\text {nd }}$ Ed. Upper Saddle River: Prentice Hall.

Lane, S.D. \& Chereks, D.R. (2001). 'Risk Taking by Adolescents with Maladaptive Behaviour'. Historical Experimental and Clinical Psychopharmacology. 9 (1) 74-82.

Lever, N. (2004). "A Drop-Out Prevention Programme for High-Risk Inner-City Youth", Behaviour Modification. 2894) 513-527.

Moore, C.W, Petty, J. W., Longenecker, J.G. (2010). Managing Small Business. China: Cengage Learning.

Pascarella, E.T. and Terenzini, P. T. (1991). How College Affect Students. San Francisco: Jossay-Bass.

Woolfolk, A. (2004). Educational Psychology. $9^{\text {th }}$ Ed. Boston: Alyn \& Bacon.

Zunker, V.G. (2006). Career Counselling. $7^{\text {th }}$ Ed. Canada: Belmont. 